\title{
Exploitation of Microorganisms, As tool for Sustainable Agriculture: A Review
}

\author{
Suliman Najmaldin' ${ }^{1}$, Satish Kumar², Diksha ${ }^{2}$ and Abaker. M. Malik ${ }^{3,4}$ \\ 1. Administration of Agriculture \& Natural Resources, Ministry of Production \& Economic Resources, Gezira State, Sudan \\ 2. Department of Microbiology, CCS Haryana Agricultural University, Hisar, India \\ 3. Department of Entomology, CCS Haryana Agricultural University, Hisar, India \\ ${ }^{4}$ Plant Protection Directorate, Gezira State, Sudan \\ DOI: $10.29322 / I J S R P .10 .10 .2020 . p 10661$ \\ http://dx.doi.org/10.29322/IJSRP.10.10.2020.p10661
}

\begin{abstract}
The current rate at which population is increasing and the land which is used for agriculture shows a disbalanced relationship forcing the scientists to think of either alternative or a way to increase food production per unit of land available. Apart from the stated fact, the current agriculture practices for instance, excessive use of chemical fertilizers, contributes to land detieoration and produces a land with high acidity, low organic matter attributing to low production of crop with high percentage of health threats. This concerning situation has led to adopt the use of Plant Growth promoting Rhizobacteria "PGRPs", which are tiny microbes with a large contribution in global processes. The present review highlights the mechanism behind PGPR activities by classifying them as direct and indirect way.
\end{abstract}

Index Terms- Biofertilizers, Plant Growth Promoting Rhizobacteria (PGPRs).

\section{INTRODUCTION}

$\mathrm{T}$ o satisfy the demand of uprising population, more and more chemical fertilizers basically nitrogen, potassium and phosphorous salts are dumped into soil with negligence over hazardous effects they possess, for example, chemical in soil puts out a green-house gas, Nitrous oxide into the atmosphere which accounts a portion of $74 \%$ of total U.S. $\mathrm{N}_{2} \mathrm{O}$ emission, making it the largest single source according to reports of 2013. (Draft U.S, 2016]. Apart from intensifying chemicals in soil, other adverse effect is the disturbance of biological relationship of plants, as the farmer artificially provide nitrogen in the form of ammonium nitrate, plant feels no need to establish any symbiotic relationship with microbes. Furthermore, nitrifying bacteria also take advantage of this excess ammonium and utilize it to produce nitrate which is then converted by denitrifying bacteria to produce $\mathrm{N}_{2} \mathrm{O}$, the excess leaches into the groundwater and remaining into the atmosphere [Galloway et al., 2008]. Also, many reports have suggested that chemical fertilizers are not sufficient enough for the plant growth as they lack multimicronutrients and low content of organic matter, although one cannot neglect the lethality they possess to human and environment health. Scientists are trying to find out a solution of effective sustainable agriculture vision where input cost can be reduced and the method should be natural way. Leading on the said path, crops produced need to be equipped with disease resistance, salt tolerance, drought tolerance, heavy metal stress tolerance and better nutritional value and all can be achieved by the use of soil micro-organisms which are small but highly efficient worker with no harm to environment (Armada et al., 2014, Calvo et al., 2014). They impart better nutritional and water capacity to the soil, along with other beneficial effects. The most potential organisms are bacteria and a class known as plant growth promoting rhizobacteria are doing wonders in agriculture fields. PGPRs are those bacteria which can colonize the roots of plants and a large number of free-living bacteria are able to enhance the plant growth via direct and indirect mechanisms (Lugtenberg and Kamilova, 2009).

\section{Plant Growth Promoting Rhizobacteria (PGPRs):}

Rhizosphere, the area around root surface have highest activity in terms of either biological relationships or the root secretion, a continuous interaction goes on by plant with the soil components and is reported to show highest microbial activity due to a confined pool of root exudates and other nutrients (Ahmad et al., 2008). So, these PGPRs, term introduced by Kloepper and Schroth [1978], paving the way for greater discoveries on PGPR, are basically the rhizobacteria which are isolated from the soil and are able to colonize the root surface to have a successful relationship with plant where microbes can fix nitrogen and can provides growth hormones to the plants. Also, it is crystal clear that microbial growth is more in rhizosphere soil, generally 10 to 100 times, as compared to bulk soil due to the presence of micro and macro nutrients (Weller and Thomashow, 1994). The type of relationship exhibited by the PGPRs towards plant include symbiotic, associative or free living (Gray and Smith, 2005), and includes protozoans, algae, fungi and bacteria, although bacteria is the most popular choice for a PGPR (Kaymak, 2010; Saharan and Nehra, 2011; Bhattacharyya and Jha, 2012). Apart from providing positive impact on plant growth by their secretions, some of the PGPRs are active against phytopathogens as well and boost the resistance of plant (Kloepper et al., 1980; Son et al., 2014). A wide range of freeliving as well as associate and symbiotic rhizobacteria species belonging to the genus Pseudomonas, Bacillus, Enterobacter, Klebsiella, Azotobacter, Azospirillum, Rhizobium and Serratia [Saharan and Nehra, 2011]. 


\section{Role OF Plant GROWTH PROMOTING RHIZOBACTERIA FOR PLANT GROWTH ENHANCEMENT:}

A systematic relationship exists among plant and rhizobacteria, initially plant secretes certain exudates in soil to attract rhizobacteria and once they are aggregated, the latter supports the plant growth by increasing nutrient availability, nitrogen fixation and providing disease resistance to plant, stimulating the plant growth and crop yield. These kinds of relationship in which two organisms are in close proximity are usually co evolved and that's how facultative intracellular endophytes came into existence (Bulgarelli et al., 2013). As stated in earlier sections there can be direct or indirect mechanisms of action, the former includes Nitrogen fixing, soil mineral solubilization, production of plant- growth-promoting substances (Auxins, Cytokinin or Gibberellins) and reduction of ethylene levels, stimulation of root growth, rhizoremediation and plant stress control while the latter includes biological control by the rhizobacteria through production of volatile organic compound, production of protection enzyme such as chitinase, glucanase and ACC-deaminase, induction of systemic resistance (Choudhary et al., 2011; García-Fraile et al., 2015). and competition for nutrients and niches for the prevention of plant diseases.

\section{DIRECT PLANT GROWTH PROMOTION:}

Bacterial are potential producers of plant hormones, the ability to produce Indole acetic acid (IAA) is wide spread among plant-associated bacteria (Gaudin et al. 1994; Patten \& Glick, 1996; Glickmann et al. 1998) and is well known for inducing early growth of roots after germination, pathogenesis and Phyto stimulation processes (Venturi and Keel, 2016). Though, IAA regulates the expression of cAMP and amino acids (Katsy, 1997), it can also modify or degrade the tryptophan residues or analogs by methylation or halogenation producing toxic compounds which are lethal to bacterial cell (Hutcheson \& Kosuge, 1985; Yamuda et al. 1985; Bar \& Okon, 1992). IAA is a multitasker and shows effects on cell division extension and differentiation, seed and tuber germination; increases the rate of xylem and root development (Gowtham et al., 2017).); vegetative growth; lateral and adventitious root formation; responses to light, gravity and florescence; photosynthesis, pigment formation, biosynthesis of various metabolites and resistance to stressful conditions (Tsavkelova et al. 2006; Spaepen et al. 2011). IAA helps in establishment of symbiotic relation by forming nodules in leguminous plants as observed for rhizobia, also it increases the root surface providing more access to nutrients (Gaudin et al. 1994).

\section{NITROGEN FIXATION:}

Among nutrient requirement of plants, nitrogen is always a limiting one, although $78 \%$ of atmosphere is occupied with nitrogen it is often unavailable to the plants. Nitrogen is one of crucial nutrient and is transformed by biological nitrogen fixation process into ammonia which is a readily absorbed by plants (Singh et al., 2015). Nitrogen fixation is carried out naturally by some of the microbes with help of an enzyme complex i.e. nitrogenase comprised of two subunits dinitrogenase and dinitrogenase reductase each differ in metallic composition (Choudhary and Varma, 2017). The former one uses the electrons provided by reductase unit to reduce $\mathrm{N}_{2}$ to $\mathrm{NH}_{3}$ which is utilized by plants. The basic nitrogenase enzyme widespread among bacterial genera or diazotrophs is molybdenum nitrogenase while some are reported to have vanadium instead of molybdenum (Mus et al., 2018). Those bacteria which are symbiotic and are capable of nitrogen fixation hosts Nif genes which are dependent on low oxygen tension which is further regulated by fix genes as observed in Rhizobium. Nif and fix genes are the sets of genes found in free living microbes as well (Wongdee et al., 2018). Several PGPR are able to colonize plant internal tissues and thus enhance their growth-promoting effect by providing a limiting oxygen environment required for activation of $\mathrm{N}_{2}$-fixation and more efficient transfer of the fixed nitrogen to the host plants (Nyoki and Ndakidemi, 2018). BNF represents an alternative to chemical fertilizers due to economic and environmental advantages.

\section{ACC DEAMINASE:}

Ethylene is an essential metabolite for plant normal growth and development (Van de Poel et al., 2015). Besides being a growth regulator, it is a hormone generated in stress situations resulting from salinity, drought or pathogenicity (Müller and Munné-Bosch, 2015). In these conditions, endogenous ethylene level increases significantly, with negative effects since it can act as a negative plant growth regulator, leading to shorter roots (epinasty), and premature senescence (Bharti and Barnawal, 2018). Thus, high ethylene concentrations can reduce crop yields. PGPR that have ACC deaminase are able to regulate ethylene production by metabolizing ACC (an immediate precursor of ethylene biosynthesis in higher plants) in $\alpha$ ketobutyrate and $\mathrm{NH}_{3}$ (Dar et al., 2018). In this way, PGPR facilitate plant growth and development since they are able to decrease ethylene levels. Thus, plant resistance to various stresses (e.g., presence of phytopathogenic bacteria, polyaromatic hydrocarbons, heavy metals, salinity and drought) is increased (Singh and Jha, 2016; Bharti and Barnawal, 2018).

\section{PHOSPHATE SOLUBILIZATION:}

Phosphorus is one of the inorganic nutrients, most required by all plants for the manufacture of phosphate containing nucleic acids, ATP and membrane lipids. It is essential for plant growth and development since it is involved in many important functions such as energetic metabolism, structural functions, signal transduction functions and transfer of genetic features through successive generations. Thus, this element is essential for cell division and for the generation of new tissues (Dissanayaka et al., 2018). Nasralla et al. (1998) stated that the phosphorus element is an essential nutrient for crop growth and height with good quality. Phosphorus (P), after nitrogen is the major plant growth-limiting nutrient despite being abundant in soils in both inorganic and organic forms which is required for maximum yield of agriculturally important crops. Most agricultural soils contain large reserves of phosphorus, a considerable part of 
which has accumulated as a consequence of regular applications of phosphate fertilizers. Chemical fertilizers added to the soils to circumvent the problem of $\mathrm{P}$ deficiency, further compound the situation by the fact that almost $75-90 \%$ of added $\mathrm{P}$ fertilizer is precipitated by $\mathrm{Fe}, \mathrm{Al}$ and $\mathrm{Ca}$ complexes present in the soils (Gyaneshwar et al. 2002). Individual or co-inoculation of PSB (phosphate solubilizing bacteria) with other groups of microorganisms enhanced the plant growth by increasing the efficiency of biological nitrogen fixation or the availability of $\mathrm{P}$ along with other trace elements and by the production of plant growth promoting (PGP) substances (Poonguzhali et al. 2005). Bacteria of various genera such as Bacillus, Pseudomonas, Mycobacterium, Azospirillum, Agrobacterium, Azotobacter, Rhizobium and Alcaligenes are included in the PGPR group (Pathak et al., 2017; Yadav et al., 2018). PSB, which belong to the PGPR group, are ubiquitous and have different properties and population levels according to the physicochemical characteristics, organic matter content and $\mathrm{P}$ of the soil where they are found. PSB can transform different $\mathrm{P}$ insoluble compounds into soluble forms available for plant uptake (Pathak et al., 2017). Phosphate-solubilizing mechanisms include solubilization of inorganic phosphates by the action of low molecular weight acids such as gluconic and citric acids, which are synthetized by soil bacteria. On the other hand, organic phosphate mineralization occurs through bacterial synthesis of phosphatases such as phytases and nucleases, which catalyze the hydrolysis of phosphoric esters, releasing the phosphate group (Novo et al., 2018). An important fact is that inorganic Psolubilization and organic $\mathrm{P}$-mineralization are capabilities that can coexist in a same bacterial strain (Hanif et al., 2015).

\section{PGPR AS BIOCONTROL AGENT:}

In general, competition for nutrients, exclusion of niches, systemic resistance induction and antagonistic metabolite production are the main modes of action through which PGPR exert biocontrol (Fukami et al., 2018). Through these mechanisms, beneficial bacteria can prevent the deleterious effect of phytopathogens on plant growth and/or development.

An indirect mechanism that was found to be involved in plant protection by beneficial bacteria is plant-mediated induced systemic resistance (ISR) that is phenotypically similar to the systemic acquired resistance (SAR) that occurs when plants activate their defence mechanisms in response to infection by a pathogenic agent (Pieterse et al. 2009). ISR-positive plants are said to be "primed" so that they react faster and more strongly to pathogen attack by inducing defence mechanisms. ISR does not target specific pathogens. Rather, it may be effective at controlling diseases caused by different pathogens. ISR involves jasmonate and ethylene signalling within the plant and these hormones stimulate the host plant's defence responses to a range of pathogens (Verhagen et al. 2004). ISR does not require any direct interaction between the resistance-inducing PGPB and the pathogen (Bakker et al. 2007). Besides ethylene and jasmonate, other bacterial molecules such as the $O$-antigenic side chain of the bacterial outer membrane protein lipopolysaccharide, flagellar proteins, pyoverdine, chitin, $\beta \beta$-glucans, cyclic lipopeptide surfactants, and salicylic acid have all been reported to act as signals for the induction of systemic resistance.
It was shown for a couple of bacteria that they are able to trigger the plant's defense system, thereby inducing a systemic resistance against pathogens. In analogy to pathogenic bacteria, also cell surface components of certain non-pathogenic microorganisms are recognized by the plant resulting in a mild but effective immune response (Van Wees et al. 2008). Such a response involves the production of pathogenesis-related (PR) proteins, the enhancement of cell wall lignification, and/or the active closing of stomata. Van Wees et al. (2000) showed that the application of Pseudomonas fluorescence strain WCS417r strain to $A$. thaliana plants stimulates a host response effective against $P$. syringae.

PGPR that indirectly enhance plant growth via suppression of phytopathogen do so by a variety of mechanism. These include: -

- The ability to produce siderophore that chelate iron, making it unavailable to pathogen.

- $\quad$ The capacity to synthesize anti-fungal metabolites such as antibiotics, fungal cell wall-lysing enzymes or hydrogen cyanide, which suppress the growth of fungal pathogens.

- The ability to successfully compete with pathogen for nutrient or specific niches on the roots.

\section{Role of Plant Growth Promoting Rhizobacteria AS A BIOFERTILIZER:}

Organic farming is gaining attention of lately, due to uprising demand of green synthesis. Biofertilizers are a substitute for chemical fertilizers and can be defined as tiny microorganisms which are applied to seeds, plants or soil so to enhance the plant growth by increasing the concentration of free nutrients in the soil which can be readily available to plant (Vessey, 2003). According to Mishra et al., [2013], a blend of live or latent cells accelerating global processes like nitrogen fixation, phosphate solubilization, mineralization, and are applied to soil, seed, roots or composting area are termed as biofertilizers. A similar definition was given by Malusá and Vassilev [2014], stating biofertilizer as a formulated product having one or more microorganism and aimed to upgrade the nutrient status by either making them readily available to plant or by increasing access to nutrients by plants. Bacteria, algae and fungi are potential biofertilizers and are grouped in two categories one is nitrogen fixers like Rhizobium, Azotobacter, Azospirillum, Acetobacter, Blue Green Algae and Azolla and phosphorous solubilizers/ mobilizers like Mycorrhizae. Few more categories have been identified recently, the potash mobilizers like Frateuria aurentia, Zinc \& Sulphur solubilizers like Thiobacillus species and manganese solubilizer fungal culture like Penicillium citrinum. These new strains would also address the issue of 'Fertilizer Use Efficiency' and would also enhance the efficacy of Bio-fertilizers (Mishra et al. 2013). Major benefits gained from these microbes includes increased recycling, mineralization and uptake of nutrients such as atmospheric nitrogen fixation, solubilization of phosphorus and potassium, synthesis of siderophores for iron sequestration, synthesis of vitamins, amino acids and plant growth regulating substances like auxins and gibberellins that cause elongation of root and shoot leading to improved plant growth (Glick, 1995). 
Moreover, these bacteria are able to feed upon contaminants like heavy metal, pesticides and reduces their concentration by microbial degradation and uptake of pollutants by plants. Further, they reduce the number of pathogens either by competition or by producing action via antibiotics, siderophores and/or hydrolytic enzymes (Saharan \& Nehra, 2011). Biofertilizer is a rapid growing industry as it is ecofriendly, cost effective, enhances crop production and soil sustainability. The functioning of biofertilizer is relatively easy to understand, they are applied as seed or soil inoculant after which they colonize and helps in nutrient cycling and crop productivity. Around, $60 \%$ to $90 \%$ of the total applied fertilizer is lost and the remaining $10 \%$ to $40 \%$ is reserved by plants. In this regard, microbial inoculants have paramount significance in integrated nutrient management systems to sustainable agricultural productivity and healthy environment (Bhardwaj et al. 2014).

\section{CONCLUSION:}

Plant growth promoting rhizobacteria is the most promising way for green synthesis and sustainable way of enhancing productivity, disease resistance and maintaining ecological balance.

\section{ACKNOWLEDGMENT:}

I am very grateful to my International colleagues for their encouragement, cooperation and sharing information.

\section{REFERENCES}

[1] Ahmad, F., Ahmad, I. and Khan, M.S. (2008). Screening of free-living rhizospheric bacteria for their multiple plant growth promoting activities. Microbiol. Res. 163, 173-181. [CrossRef] [PubMed]

[2] Armada, E., Portela, G., Roldan, A. and Azcon, R. (2014). Combined use of beneficial soil microorganism and agro waste residue to cope with plant water limitation under semiarid conditions. Geoderma. 232, 640-648. [CrossRef]

[3] Bakker, P.A.H.M., Pieterse, C.M.J. and Van Loon, L.C. (2007). Induced systemic resistance by fluorescent Pseudomonas sp., Phytopathology, 97, 239-243.

[4] Bar, T. \& Okon, Y. (1992). Induction of indole-3-acetic acid synthesis and possible toxicity of tryptophan in Azospirillum brasilense Sp7. Symbiosis, 13, 191-198.

[5] Bhardwaj, D., Ansari, M. W., Sahoo, R. K. and Tuteja, N. (2014). Biofertilizers function as key player in sustainable agriculture by improving soil fertility, plant tolerance and crop productivity. Microbial Cell Factories, 13, 66.

[6] Bharti, N. and Barnawal, D. (2018). Amolioration of salinity stress by PGPR: ACC deaminase and ROS scavenging enzyme activity. In: Singh, A.K., Kumar, A., Singh, P.K. (Eds.), PGPR Amolioration in Sustainable Agriculture: Food Security and Environmental Management. Woodhead Publishing, United Kingdom. 85-106.

[7] Bharti, N., Sharma, S.K., Saini, S., Verma, A., Nimonkar, Y. and Prakash, O. (2017). Microbial plant probiotics: problems in application and formulation. In: Kumar, V., Kumar, M., Sharma, S., Prasad, R. (Eds.), Probiotics and Plant Health. Springer, Singapore. 317-335.

[8] Bhattacharyya, P.N. and Jha, D.K. (2012). Plant growth-promoting rhizobacteria (PGPR): Emergence in agriculture. Wood J. Microb. Biotechnol. 28, 1327-1350. [CrossRef] [PubMed]
[9] Bulgarelli, D., Schlaeppi, K., Spaepen, S., Themaat, E. and Lefert, P. (2013). Structure and functions of the bacterial microbiota of plants. Annual Review of Plant Biology, 64, 807-838.

[10] Burdman, S., Jurkevitch, E. and Okon, Y. (2000). Recent advances in the use of plant growth promoting rhizobacteria (PGPR) in agriculture. In Microbial Interactions in Agriculture and Forestry; Subba Rao, N.S., Dommergues, Y.R., Eds.; Science Publishers: Enfield, NH, USA, 14, 229 250 .

[11] Calvo, P., Nelson, L.M. and Kloepper, J.W. (2014). Agricultural uses of plant biostimulants. Plant Soil. 383, 3-41. [CrossRef]

[12] Choudhary, D.K. and Verma, A. (2017). Nitrogenase (a key enzyme): structure and function. In: Hansen, A., Choudhary, D., Agrawal, P., Varma, A. (Eds.), Rhizobium Biology and Biotechnology. Springer, Cham. 293307.

[13] Choudhary, D.K., Sharma, K.P. and Gaur, R.K. (2011). Biotechnological perspectives of microbes in agro-ecosystems. Biotechnol. Lett. 33, 19051910. [CrossRef] [PubMed]

[14] Dar, Z.M., Masood, A., Mughal, A.H., Asif, M. and Malik, M.A. (2018) Review on drought tolerance in plants induced by plant growth promoting rhizobacteria. Int. J. Curr. Microbiol. Appl. Sci. 7, 412-422. https://doi.org/10.20546/ijcmas.2018.705.053.

[15] Dissanayaka, D.M.S.B., Plaxton, W.C., Lambers, H., Siebers, M., Marambe, B. and Wasaki, J. (2018). Molecular mechanisms underpinning phosphorus- use efficiency in rice. Plant Cell Environ. 41, 1483-1496. https://doi.org/10.1111/pce.13191.

[16] Draft U.S. Greenhouse Gas Inventory Report: 1990-2014. Available online: https://www3.epa.gov/ climatechange/ghgemissions/usinventoryreport.html (accessed on 23 March 2016).

[17] Fukami, J., Cerezini, P. and Hungria, M. (2018). Azospirillum: benefits that go far beyond biological nitrogen fixation. AMB Express. 8, 73. https://doi.org/10.1186/s13568- 018-0608-1.

[18] Galloway, J.N., Townsend, A.R., Erisman, J.W., Bekunda, M., Cai, Z., Freney, J.R., Martinelli, L.A., Seitzinger, S.P. and Sutton, M.A. (2008). Transformation of the nitrogen cycle: Recent trends, questions, and potential solutions. Science. 320, 889-892. [CrossRef] [PubMed]

[19] García-Fraile, P., Menéndez, E. and Rivas, R. (2015). Role of bacterial biofertilizers in agriculture and forestry. AIMS Bioeng. 2, 183-205. [CrossRef]

[20] Gaudin, V., Vrain, T. \& Jouanin, L. (1994). Bacterial genes modifying hormonal balance in plants. Plant Physiology and Biochemistry. 32, 11-29.

[21] Gaudin, V., Vrain, T. and Jouanin, L. (1994). Bacterial genes modifying hormonal balance in plants. Plant Physiology and Biochemistry. 32, 11-29.

[22] Glick, B. R. (1995). The enhancement of plant growth by free-living bacteria. Canadian Journal of Microbiology. 41, 109-117.

[23] Glick, B.R. (2012). Plant Growth-Promoting Bacteria: Mechanisms and Applications; Hindawi Publishing Corporation, Scientifica: Waterloo, Canada.

[24] Glickmann, E., Garden, L., Jaeguet, S., Hussain, S., Elasri, M., Petit, A. and Dessaux, Y. (1998). Auxin production is a common feature of most pathovars of Pseudomonas syringae. Moecular Plant-Microbe Interactions. $11,156-162$.

[25] Gray, E.J. and Smith, D.L. (2005). Intracellular and extracellular PGPR Commonalities and distinctions in the plant-bacterium signaling processes. Soil Biol. Biochem. 37, 395-412. [CrossRef]

[26] Gyaneshwar, P., Naresh, K.G., Parekh, L.J. and Poole, P.S. (2002). Role of soil microorganisms in improving P nutrition of plants. Plant and Soil. 245, 83-93.

[27] Hanif, K., Hameed, S., Imran, A., Naqqash, T., Shahid, M. and Van Elsas, J.D. (2015). Isolation and characterization of a $\beta$-propeller gene containing phosphobacterium Bacillus subtilis strain KPS-11 for growth promotion of potato (Solanum tuberosum L.). Front. Microbiol. 6, 583. https://doi.org/10.3389/fmicb.2015.00583.

[28] https://doi.org/10. 1104/pp.15.00724.

[29] Hutcheson, S.W. and Kosuge, T. (1985). Regulation of 3-indole acetic acid production in Pseudomonas syringae pv. Savastanoi. Journal of Chemistry. 260, 6281-6287.

[30] Katsy, E.I. (1997). Participation of auxin in regulation of bacterial and plant gene expression. Russian Journal of Genetics. 33, 463-473. 
[31] Kaymak, D.C. (2010). Potential of PGPR in agricultural innovations. In Plant Growth and Health Promoting Bacteria; Maheshwari, D.K., Ed.; Springer-Verlag: Berlin/Heidelberg, Germany.

[32] Kloepper, J.W. and Schroth, M.N. (1978). Plant growth-promoting rhizobacteria on radishes. In Station de Pathologie, Proceedings of the 4th International Conference on Plant Pathogenic Bacteria, Tours, France, 27 August-2 September 1978; Végétale et Phyto-Bactériologie, Ed. 879-882.

[33] Kloepper, J.W., Leong, J., Teintze, M. and Schroth, M.N. (1980). Enhanced plant growth by siderophores produced by plant growth promoting rhizobacteria. Nature. 286, 885-886.

[34] Lugtenberg B, and Kamilova F. (2009). Plant growth promoting rhizobacteria. Annu. Rev. Microbial. 63, 541 - 556.

[35] Malusá, E. and Vassilev, N. (2014). A contribution to set a legal framework for biofertilizers. Appl. Microbial. Biotechnol. 98, 6599-6607. [CrossRef] [PubMed]

[36] Mishra D.J., Singh, R., Mishra U.K. and Kumar, S. S. (2013). Role of BioFertilizer in Organic Agriculture: A Review.Research Journal of Recent Sciences. 2, 39-41.

[37] Mishra, D., Rajvir, S., Mishra, U. and Kumar, S.S. (2013). Role of biofertilizer in organic agriculture: A review. Res. J. Recent Sci. 2, 39-41.

[38] Müller, M. and Munné-Bosch, S. (2015). Ethylene response factors: a key regulatory hub in hormone and stress signaling. Plant Physiol. 169, 32-41. https://doi.org/10.1104/pp.15.00677.

[39] Mus, F., Alleman, A.B., Pence, N., Seefeldt, L.C. and Peters, J.W. (2018). Exploring the alternatives of biological nitrogen fixation. Metallomics. 10, 523-538. https://doi.org/10. 1039/C8MT00038G.

[40] Nasr aala, A.E., Osam, A.A.O. and Soliman, K.G. (1998). Effect of increased phosphorus and potassium or sulphur application in there different combinations on yield, components and chemical composition of Peanut in a newly reclaimed sandy soil. Zagazig Journal of Agricultural Research. 25, 557-579

[41] Novo, L.A., Castro, P.M., Alvarenga, P. and da Silva, E.F. (2018). Plant growth promoting rhizobacteria-assisted phytoremediation of mine soils. In: Prasad, M.N.V., de Campos Favas, P.J., Maiti, S.K. (Eds.), BioGeotechnologies for Mine Site Rehabilitation. Elsevier Inc., Amsterdam, 281-295.

[42] Nyoki, D. and Ndakidemi, P.A. (2018). Root length, nodulation and biological nitrogen fixation of Rhizobium inoculated soybean (Glycine max [L.] Merr.) grown under maize (Zea mays L.) intercropping systems and $\mathrm{P}$ and $\mathrm{K}$ fertilization. Adv. Biores. 9, 173-180. https://doi.org/10.15515/abr.0976-4585.9.1.173180.

[43] Pathak, D.V., Kumar, M. and Rani, K. (2017). Biofertilizer application in horticulture crops. In: Panpatte, D.G., Jhala, Y.k., Vyas, R.V., Shelat, H.N. (Eds.), Microorganisms for Green Revolution. Springer, Singapore. 215227.

[44] Patten, C.L. and Glick, B.R. (1996). Bacterial biosynthesis of indole-3acetic acid. Canadian Journal of Microbiology. 42, 207-220.

[45] Pieterse, C.M.J., Leon-Reyes, A., Van der Ent, S. and Van Wees, S.C.M. (2009). Networking by small-molecule hormones in plant immunity. Nature Chemical Biology. 5, 308-316.

[46] Poonguzhali, S., Madhaiyan, M., Thangaraju, M., Ryu, J.H., Chung, K.Y. and Sa, T.M. (2005). Effects of co-cultures, containing N-fixer and Psolubilizer, on the growth and yield of Pearl millet (Pennisetum glaucum (L.) R. Br.) and Blackgram (Vigna mungo L.). Journal of Microbiolgy and Biotechnology. 15, 903-908.

[47] Saharan, B. S. and Nehara, V. (2011). Plant Growth Promoting Rhizobacteria: A Critical Review. Life Sciences and Medicine Research. 21, 1-30.

[48] Saharan, B.S. and Nehra, V. (2011). Plant growth promoting rhizobacteria: A critical review. Life Sci. Med. Res. 21, 1-30.

[49] Singh, R. P., Jha, P. and Jha P. N. (2015). The plant-growth-promoting bacterium Klebsiella sp. SBP-8 confers induced systemic tolerance in wheat (Triticum aestivum) under salt stress. Journal of Plant Physiology. 184, 5767.
[50] Singh, R.P. and Jha, P.N. (2016). The multifarious PGPR Serratia marcescens CDP-13 augments induced systemic resistance and enhanced salinity tolerance of wheat (Triticum aestivum L.). PLoS One 11, e0155026. https://doi.org/10.1371/journal.pone.0155026.

[51] Son, J.S., Sumayo, M., Hwang, Y.J., Kim, B.S. and Ghim, S.Y. (2014) Screening of plant growth promoting rhizobacteria as elicitor of systemic resistance against grey leaf spot dieses in pepper. Appl. Soil Ecol. 73, 1-8. [CrossRef]

[52] Spaepen, S. and Vanderleyden, J. (2011). Auxin and plant-microbe interactions, Cold Spring Harbor perspectives in biology. 3, 4 .

[53] Tsakelova, E.A., Klimova, S.Y., Cherdyntseva, T. A. and Netrusov, A.I. (2006). Microbial producers of plant growth stimulators and their practical use: a review. Applied Biochemistry and Microbiology. 42, 117-126.

[54] Van de Poel, B., Smet, D. and Van Der Straeten, D. (2015). Ethylene and hormonal cross talk in vegetative growth and development. Plant Physiol. $169,61-72$.

[55] Van Wees, S.C., De Swart, E.A., Van Pelt, J.A., Van Loon, L.C. and Pieterse, C.M. (2000). Enhancement of induced disease resistance by simultaneous activation of salicylate- and jasmonate dependent defense pathways in Arabidopsis thaliana. Proceedings of the National Academy of Sciences USA. 97, 8711-8716.

[56] Van Wees, S.C., Van der Ent, S. and Pieterse, C.M. (2008). Plant immune responses triggered by beneficial microbes. Current Opinion Plant Biology. $11,443-448$.

[57] Venturi, V. and Keel, C. (2016). Signaling in the rhizosphere. Trends Plant Sci. 21, 187-198. https://doi.org/10.1016/j.tplants.2016.01.005.

[58] Verhagen, B.W.M., Glazebrook, J., Zhu, T., Chang, H.S., Van Loon, L.C. and Pieterse, C.M.J. (2004). The transcriptome of rhizobacteria-induced systemic resistance in Arabidopsis. Molecular Plant-Microbe Interactions. $17,895-908$.

[59] Vessey, J. K. (2003). Plant growth promoting rhizobacteria as biofertilizers Plant and Soil. 255, 571-586.

[60] Weller, D.M. and Thomashow, L.S. (1994). Current challenges in introducing beneficial microorganisms into the rhizosphere. In Molecular Ecology of Rhizosphere Microorganisms: Biotechnology and Release of GMOs; O’Gara, F., Dowling, D.N., Boesten, B., Eds.; VCH: New York, NY, USA. 1-18.

[61] Wongdee, J., Boonkerd, N., Teaumroong, N., Tittabutr, P. and Giraud, E. (2018). Regulation of nitrogen fixation in Bradyrhizobium sp. strain DOA9 involves two distinct NifA regulatory proteins that are functionally redundant during symbiosis but not during free-living growth. Front. Microbiol. 9, 1644. https://doi.org/10.3389/fmicb.2018. 01644.

[62] Yadav, S.K., Soni, R. and Rajput, A.S. (2018). Role of microbes in organic farming for sustainable agro-ecosystem. In: Panpatte, D.G., Jhala, Y.K., Shelat, H.N., Vyas, R.V. (Eds.), Microorganisms for Green Revolution. Microorganism for Sustainability. Springer, Singapore. 241-252.

[63] Yamuda, T., Palm, C. J., Brooks, B. and Kosuge, T. (1985). Nucleotide sequence of the Pseudomonas savastanoi indole acetic acid show homology with Agrobacterium tumefaciens T-DNA. Proceedings of the National Academy of Sciences, USA. 82, 6522-6526.

\section{AUTHORS}

First Author - Suliman Najmaldin, Administration of Agriculture \& Natural Resources, Ministry of Production \& Economic Resources, Gezira State, Sudan

Second Author - Satish Kumar, Department of Microbiology,

CCS Haryana Agricultural University, Hisar, India

Third Author - Diksha, Department of Microbiology, CCS

Haryana Agricultural University, Hisar, India

Fourth Author - Abaker. M. Malik, Department of

Entomology, CCS Haryana Agricultural University, Hisar, India

Plant Protection Directorate, Gezira State, Sudan 
